\title{
Trichorhinophalangeal syndrome as a diagnostic and therapeutic challenge for paediatric endocrinologists
}

Zespół włosowo-nosowo-paliczkowy jako diagnostyczne i terapeutyczne wyzwanie dla endokrynologa dziecięcego

\author{
Elżbieta Foryś-Dworniczak, Olimpia Zajdel-Cwynar, Barbara Kalina-Faska, Ewa Małecka-Tendera, \\ Paweł Matusik
}

Department of Paediatrics and Paediatric Endocrinology, School of Medicine in Katowice, Medical University of Silesia, Katowice, Poland

\begin{abstract}
Trichorhinophalangeal syndrome (TRPS) is rare genetic disorder with autosomal dominant inheritance. The TRPS1 gene is located on the long arm of the eighth chromosome (8q24.12). The phenotype is variable and presents a wide clinical spectrum. Most cases are characterised by thin, sparse scalp hair, distinctive facial dysmorphism, and various skeletal abnormalities, especially of the hands and feet. Characteristic facial features may include a "pear-shaped" nose, micrognathia, dental anomalies, prominent ears, elongated philtrum, and thin upper vermillion border. In most cases, affected individuals exhibit skeletal abnormalities including brachydactyly and clinodactyly, short metacarpals phalanges, short feet and metatarsals, and pectus carinatum and hip joint malformations. Additionally, patients may exhibit short stature.

This report presents four cases of TRPS (three sporadic and one familial). Clinical presentation included typical facial features and various skeletal abnormalities. Some TRPS symptoms may mimic growth hormone deficiency and other endocrine disturbances. The aim of this article is to deliver TRPS symptomatology. The treatment of TRPS is symptomatic and supportive and requires the coordination of several specialists, including paediatricians, endocrinologists, orthopaedic surgeons, dermatologists, and medical rehabilitation and dental specialists. In some cases, recombinant growth hormone therapy may be necessary. Genetic counselling may be of benefit for affected individuals and their families.
\end{abstract}

Key words:

trichorhinopharyngeal syndrome, skeletal abnormalities, short stature.

\section{Streszczenie}

Zespół włosowo-nosowo-paliczkowy jest rzadką chorobą uwarunkowaną genetycznie, w większości przypadków o autosomalnie dominującym sposobie dziedziczenia. Gen TRPS1 jest zlokalizowany na długim ramieniu chromosomu 8 - 8q24(8q24.12). Fenotyp jest zróżnicowany i prezentuje szerokie spektrum objawów klinicznych. Do charakterystycznych cech fenotypowych zalicza się rzadkie włosy, dysmorfię twarzoczaszki oraz zaburzenia kostno-szkieletowe, zwłaszcza w obrębie dłoni i stóp. Do typowych cech dysmorficznych twarzy należą: "gruszkowaty nos", mikrognacja, anomalie zębowe, wydatne uszy, wydłużona rynienka nosowa i wąska czerwień wargowa. W większości przypadków występują anomalie szkieletowe, takie jak klino- i brachydaktylia, skrócenie paliczków śródręcza i śródstopia, kurza klatka piersiowa oraz malformacje stawu biodrowego. Część pacjentów ma niedobór wzrostu. Artykuł przygotowano na podstawie serii czterech przypadków klinicznych (trzy sporadyczne i jeden rodzinny). Wszystkie dzieci prezentowały typowe dla TRPS cechy dysmorfii twarzoczaszki oraz różne anomalie układu kostno-szkieletowego. Przyczyną skierowania na Oddział Endokrynologii Dziecięcej było podejrzenie różnych endokrynopatii, w tym niedobór hormonu wzrostu, zaburzeń gospodarki wapniowo-fosforanowej czy zespołu Turnera. Celem pracy jest przybliżenie symptomatologii TRPS. Leczenie jest objawowe i wymaga skoordynowanej współpracy wielu specjalistów, w tym lekarza pediatry, endokrynologa, ortopedy, dermatologa, specjalisty rehabilitacji medycznej czy chirurga szczękowego. Część pacjentów z niskorosłością i niedoborem GH może wymagać terapii substytucyjnej rGH. Doradztwo genetyczne może przynieść korzyści dotkniętym TRPS osobom i ich rodzinom.

\section{Słowa kluczowe:}

zespół włosowo-nosowo-paliczkowy, anomalie szkieletowe, niskorosłość.

Received 15.012019

Accepted: 20.02.2019

Conflict of interests: none declared.
Assoc. Prof. Pawel Matusik

Department of Paediatrics and Paediatric Endocrinology

Upper-Silesian Child Health Centre

Medyków 16, 40-752 Katowice, Poland

tel. +483220716 54, fax: +48322071653

e-mail: endocrin@wp.pl; pmatusik73@gmail.com 


\section{Introduction}

Trichorhinopharyngeal syndrome (TRPS) is an autosomal dominant malformation syndrome, characterised by craniofacial and skeletal abnormalities with variable expressivity [1]. The first case of TRPS was reported by Giedion in 1966 [2]. Three clinically and molecularly distinguishable types of TRPS (TRPSs I, II, and III) have been described in the literature. TRPS type I (Giedion syndrome) is caused by alternations of chromosome 8 band q 24.1, including deletions, insertions, or translocations [1]. TRPS type II (Langer-Giedion syndrome, LGS) is a contiguous gene syndrome with larger deletion, involving loss of functional copies of the TRPS1 gene at 8q23.3 and EXT1 gene at $8 q 24.11$ [3]. TRPS type III is almost exclusively caused by missense mutations in the GATA DNA-binding zinc finger of TRPS1 protein. Ludacke et al. (2001) suggested that TRPS III is a subclass of TRPS I, which is supposed to be at the severe end of the TRPS spectrum [4].

The TRPS1 gene was identified and mapped to chromosomal band $8 \mathrm{q} 24$ by Momeni et al. [1]. TRPS gene encode a zinc-finger, GATA-type transcription factor, which is involved in the development and differentiation of the bones, kidneys, and hair follicles [1]. In recent articles a possible role of TRPS1 in determining bone mineral density and influencing on bone homeostasis has been described [5,6]. Mutations or haploinsufficiency at TRPS1 is the major cause of TRPS I and III. So far five molecular classes of TRPS1 mutation have been found: deletion or disruption, nonsense mutation, in-frame splice mutation, missense mutation, or no mutation identified [4]. The establishment of genotype-phenotype correlation revealed variability of clinical features.

EXT1 is a tumour suppressor gene, which encodes exostosin-1, and which, with EXT2, forms a hetero-oligomeric complex playing an essential role in the regulation of chondrocyte differentiation, ossification, and apoptosis. The loss of the both functional copies of them causes multiple exostoses in TRPS type II. Mutations in EXT1 are also associated with development of chondrosarcoma $[7,8]$.

Trichorhinophalangeal syndrome is characterised by distinctive facial dysmorphic features and various skeletal abnormalities. The phenotype was variable and present a wide clinical spectrum. Features common to all three types are fine, slowly growing, sparse scalp hair, often of poor quality, breaking and pulling out easily. In addition, facial features also included pear-shaped nose with a bulbous tip, hypoplastic nasal alae nasi, low-set, protruding ears, and prominent malar eminence and orbital ridge. Highly characteristic are elongated philtrum, thin upper vermillion border, broad, laterally sparse eyebrows, and triangular face $[2,3,9,10]$. Sparseness of hair may also affect the eyelashes, bear, axillary, and pubic hair [7]. Thin, fragile, slowly growing nails have been described. Additional nail changes in TRPS include leukonychia, koilonychia, onychodystrophy, and longitudinal striation $[5,11]$. The oral changes, such as malocclusion, supernumerary teeth, microdontal teeth, hypodontia, and micrognathia or bilateral dysplasia of the mandibular condyles have been described in a few cases $[12,13]$.
The skeletal abnormalities include short stature, brachioand clinodactyly, short metacarpal phalanges, short feet and metatarsals, winged scapula, pectus carinatum, and scoliosis [2]. In addition, in TRPS II patients joint hyper-extensibility, syndactyly, and predisposition to fracture can occur.

The most typical radiographic findings are cone-shaped epiphyses (CSEs), mostly at the middle phalanges. They can be undetectable before two years of age [4]. However, in some cases, the first manifestation of CSEs could be mild metaphyseal convexity [14]. CSEs irregular growth of phalanges and premature closure of growth plates leads to clino- and brachydactyly. Furthermore, those changes can also be found at other tubular bones. Hip malformation such as coxa magna, coxa plana, or coxa vara are present in more than $70 \%$ of patients [4]. The skeletal age is retarded behind the chronological age until puberty and then typically accelerates. Grow retardation occurs in the postnatal period and is a progressive process $[2,4,5]$. Evaluation of skeletal abnormalities reveal a wide clinical spectrum, but it is found that patients with missense mutation tend to be more severely affected than patients with nonsense mutations.

Trichorhinopharyngeal syndrome type II differs from TRPS type I by the presence of multiple exostoses and mild to severe mental retardation [4]. TRPS type II/LGS is also associated with laxity of joints, looseness of the skin, microcephaly, deep-set eyes, exotropia, tented, thickened nasal alae, and conductive hearing loss [15]. TRPS type III differs clinically from TRPS I by the presence of severe brachydactyly, due to short metacarpals and severe short stature [3].

In addition, malformations of inner organs have been reported in the literature, as well. Besides disorders of the ureterbladder junction, vesicoureteral reflux, renal defect [9] heart failure like ventricular septal defects (VSD), or mitral valve prolapse (MVP) have been described in several patients [16-18]. Growth hormone deficiency, hypothyroidism, or diabetes mellitus was previously reported in a few cases [19].

\section{Case reports}

This report presents a series of four cases of TRPS (three sporadic and one familial). Clinical presentation included typical facial dysmorphic features (pear-shaped nose, long, flat philtrum, thin upper vermilion border, and protruding ears), thin, sparse scalp hair, and different skeletal abnormalities with normal mentation.

\section{Case 1}

A 5.5-year-old boy with short stature was referred to the department of endocrinology for growth retardation. The diagnosis of TRPS was suggested based on typical craniofacial features including triangular face, bulbous, pear-shaped nose, elongated philtrum, sparse and slow-growing hair, rarefaction of the lateral eyebrow portion, and protruding ears.

$\mathrm{He}$ was born as the third child of non-consanguineous parents. Pregnancy was complicated by incompetence of the 
cervix uteri, and Caesarean section was performed at gestational week 37. Birth weight was $2900 \mathrm{~g}$, and length was $53 \mathrm{~cm}$. Psychomotor development was appropriate, but after the first year of life the patient manifested growth failure. At the age of two years, he was hospitalised on the department of gastroenterology due to growth deficiency. Thorough examination of the patient and laboratory analyses did not confirm malabsorption syndrome. During presentation, his height was $103.6 \mathrm{~cm}$ ( $<3^{\text {rd }}$ centile), weight was $16.3 \mathrm{~kg}$ (3 ${ }^{\text {rd }}$ centile), and BMl was $15.2\left(25-50^{\text {th }}\right.$ centile). Physical examination showed typical facial dysmorphic features and short stature. Clinically there were no skeletal abnormalities, but radiological assessment confirmed cone-shaped epiphyses at the phalanges and delayed skeletal maturation (Fig. 1). General laboratory tests of blood and urine were normal, and $\mathrm{GH}$ provocation test with clonidine showed proper GH peaks. No disturbances of calcium-phosphate metabolism were found (Table 1). Moreover, the patient's father and one of his brothers manifested a similar phenotype (not genetically confirmed yet)

\section{Case 2}

A 12-year-old girl hospitalised with growth velocity retardation, with clinical and radiological epiphyseal deformities in phalanges, right humerus, and brachydactyly of toes

She was born as the first child of healthy, non-consanguineous parents. Both parents and a younger sister were healthy and of normal height. She was born at gestational week 40, birth weight was $2900 \mathrm{~g}$, and length was $52 \mathrm{~cm}$. The postnatal period was complicated by uretero-pelvic junction stricture. Additionally, she had belatedly overgrowing of fontanelle. During the first years of life the girl manifested failure to thrive, delayed psychomotor development, and hyper-flexible joints. Her parents mentioned that she had no hair growth until the age of three years and now had thin scalp hair of poor quality, easily broken and pulling out. From the age of 10 years, she had been suffering from chronic pain of hand joints.

At the time of hospitalisation, the patient's height was $148.5 \mathrm{~cm}\left(10^{\text {th }}-25^{\text {th }}\right.$ centile $)$, and weight was $40.6 \mathrm{~kg}\left(25^{\text {th }}-50^{\text {th }}\right.$ centile). Physical examination showed typical TRPS I craniofacial and skeletal abnormalities such as sparse, slowly growing hair, a bulbous, pear-shaped nose, and short stature. Moreover, she had triangular face, laterally sparse eyebrows, thin upper vermillion border, long, flat philtrum, and protruding ears, which is highly characteristic. Radiographic examination revealed bone age retardation (bone age 11 years vs. 12 years and 3 months of chronological age). Her hands were remarkable for clino- and brachydactylia. She had short, flat feet and knock-knees. The most severe skeletal abnormality was shoulder joint deformity with limitation of radiation and abduction. Endocrinological evaluation revealed normal level of thyroid hormones, cortisol, parathyroid hormone, and IGF-1. Apart from mild 25-OH D3 insufficiency, no disturbances of calcium and phosphate balance were observed (Table 1). MRI of the brain and pituitary region were normal. Genetic analysis revealed interstitial heterozygous microdeletion of 8q24 and confirmed TRPS type 1 diagnosis.

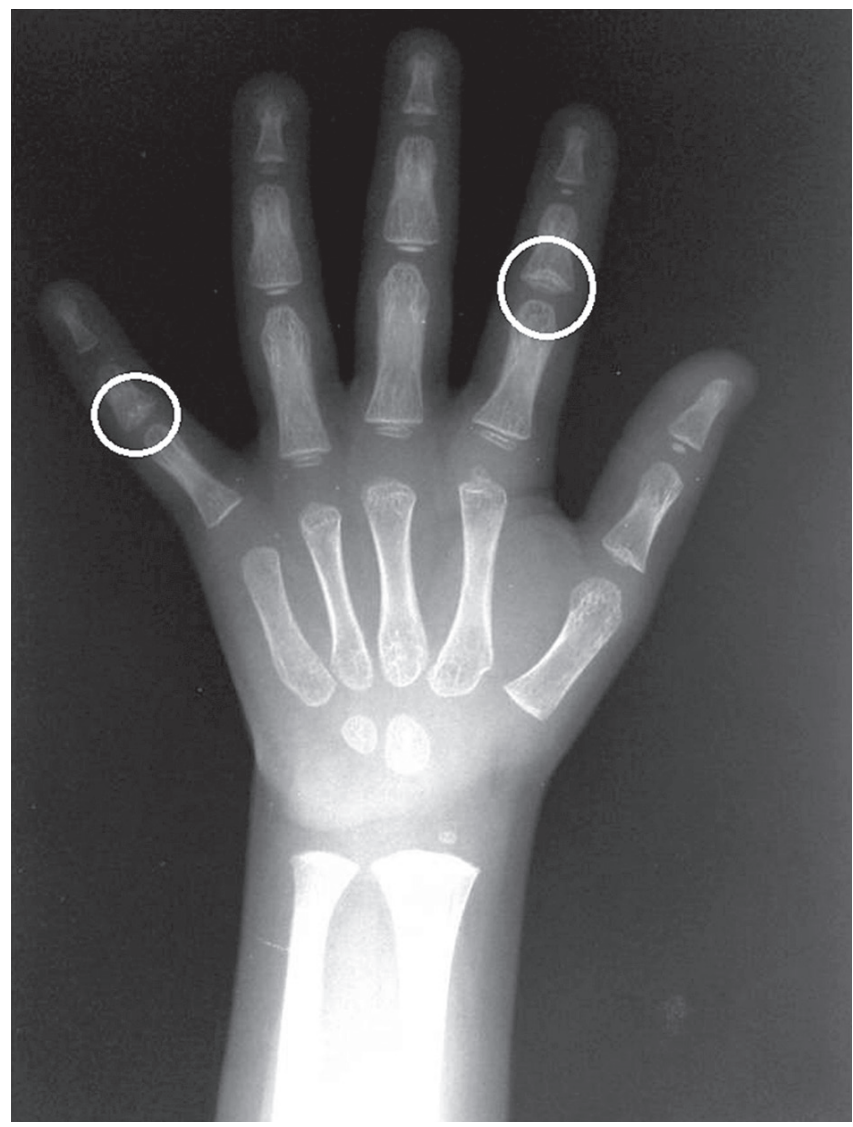

Figure 1. Cone-shaped epiphyses of middle phalanges (Case 1)

\section{Case 3}

A 13.5-year-old girl with short stature (GH deficiency excluded), typical epiphyseal deformities in phalanges, and Perthes-like left hip deformation.

The girl was admitted to the department of endocrinology for diagnosis of short stature. She was born at the $37^{\text {th }}$ week of gestation with low birth weight $\left(2000 \mathrm{~g},<3^{\text {rd }}\right.$ centile) and short length ( $44 \mathrm{~cm},<3^{\text {rd }}$ centile). The patient's mother smoked and abused alcohol during pregnancy. Significant failure to thrive was noted, with length and weight remaining below the $3^{\text {rd }}$ centile. The psychomotor development was assessed as below average for the child's age. A neurodevelopmental disorder was recognised. She had positive medical history of Perthes disease-like left femoral head changes and left coxa subluxation. In addition, she had recurrent urinary tract infections. Genetic analysis confirmed interstitial heterozygous microdeletion of 8q24.

During presentation her height was $144.9 \mathrm{~cm}\left(<3^{\text {rd }}\right.$ centile) and her weight was $35.8 \mathrm{~kg}\left(<3^{\text {rd }}\right.$ centile). The physical examination revelled facial dysmorphic features including pearshaped nose and long philtrum, wide mouth with thin upper lip, micrognathia, protruding ears, and sparse hair (Fig. 2). UInar deviation of II digits and radial deviation of IV digits of both 
Table I. The result of biochemical and hormonal analyses

\begin{tabular}{|c|c|c|c|c|}
\hline Parameter & Case 1 & Case 2 & Case 3 & Case 4 \\
\hline Sex & $\hat{\sigma}$ & q & 우 & 우 \\
\hline Age & 5 y $6 \mathrm{~m}$ & 12 y 3 m & 13 y $6 \mathrm{~m}$ & $11 y$ \\
\hline Bone age & $3 y$ & $11 \mathrm{y}$ & $13 y$ & 6 y 10 m \\
\hline Hight (cm) & $103.6(<3$ c.) & 148.5 (10-25 c.) & 144.9 (< 3 c.) & 124.3 (< 3 c.) \\
\hline Max. GH (night profile) (ng/ml) & 15.5 & - & $9.7 \downarrow$ & $3.8 \downarrow$ \\
\hline Max. GH (after clonidine) (ng/ml) & - & - & 12.3 & $7.5 \downarrow$ \\
\hline GH (after insulin) (ng/ml) & - & - & - & $5.4 \downarrow$ \\
\hline IGF-1 (ng/ml) & 79 & 603 & 404 & 168 \\
\hline $\mathrm{TSH}(\mu \mathrm{lU} / \mathrm{ml})$ & 2.79 & - & 1.29 & 2.91 \\
\hline $\mathrm{fT} 4$ (ng/dl) & 1.06 & - & 1.47 & 1.55 \\
\hline $\mathrm{LH}(\mathrm{mlU} / \mathrm{ml})$ & $<0.10$ & - & 2.2 & $<0.0$ \\
\hline $\mathrm{FSH}(\mathrm{mlU} / \mathrm{ml})$ & 0.85 & - & 5.66 & 3.32 \\
\hline Oestradiol/testosterone (pmol/l) & $<2.5$ & - & 262 & $<18.35$ \\
\hline Cortisol ( $\mu \mathrm{g} / \mathrm{dl})$ & 24.4 & 19.7 & 17.2 & 26.4 \\
\hline Parathormone (pg/ml) & - & 59.6 & 31.4 & 32.3 \\
\hline $25 \mathrm{OH}-\mathrm{D}_{3}(\mathrm{ng} / \mathrm{ml})$ & - & $11.78 \downarrow$ & $18.8 \downarrow$ & $15.2 \downarrow$ \\
\hline $\mathrm{Ca}(\mathrm{mmol} / \mathrm{l})$ & 2.47 & 2.35 & 2.54 & 2.55 \\
\hline $\mathrm{P}(\mathrm{mmol} / \mathrm{l})$ & 1.74 & 1.59 & 1.51 & 1.51 \\
\hline $\mathrm{FA}(\mathrm{U} / \mathrm{I})$ & 143 & 326 & 307 & 255 \\
\hline 24-hour Ca excretion with urine (mmol/kg/24 h): & - & 0.02 & 0.02 & - \\
\hline $\operatorname{TRP}(\%):$ & - & 85 & 91 & - \\
\hline
\end{tabular}

GH - growth hormone; IGF-1 - insulin-like growth factor 1; TSH - thyroid stimulating hormone; LH - luteinising hormone; FGH- follicle-stimulating hormone; $\mathrm{Ca}$ - calcium; P - phosphates; FA - alkaline phosphatase; TRP - phosphate resorption rate

hands at the proximal interphalangeal joint were also observed (Fig. 3). Examination of the patient's feet showed minor syndactyly of II and III toes, shortening of I, IV, and V metacarpals, and hypoplastic nails (Fig. 4). Radiographic examination showed skeletal abnormalities, such as cone-shaped epiphyses of the middle and proximal phalanges and shortened metacarpal IV. The bone age was the same as her biological age. GH provocation test with clonidine showed proper GH peaks. The levels of thyroid hormone, cortisol, parathyroid hormone, LH, FSH, and E2 were normal. However, endocrinological evaluation revealed mildly decreased 25-hydrokxyvitamin D level and elevated alkaline phosphatase level. The result of 24-hour urine col- lection showed border calcium excretion, and the phosphate resorption rate was within the normal range (Table 1). MRI of the brain and pituitary region was appropriate. Interestingly, no TRPS features were found in her twin sister.

\section{Case 4}

An 11-year-old girl was referred to the Department of Paediatrics and Paediatric Endocrinology due to short stature with concomitant facial dysmorphic features with the suspicion of Turner Syndrome.

She was born as the first child of no consanguineous parents, by natural delivery, at gestational week 39. Her birth weight 
was $2960 \mathrm{~g}$ and length was $49 \mathrm{~cm}$. The psychophysical development during the postnatal period was normal. Significant failure to thrive was noted at the age of five years. Bilateral Perthes disease was recognised at the age of six years.

On admission to the hospital at age 11 years, the patient's length was $124.3 \mathrm{~cm}$ ( $9 \mathrm{~cm}$ below the $3^{\text {rd }}$ centile) and her weight was $36.9 \mathrm{~kg}\left(25^{\text {th }}-50^{\text {th }}\right.$ centile). Physical examination showed facial dysmorphic features (triangular face, micrognathia, higharched palate, flat philtrum) and sparse, thin hair. Laboratory findings revealed reduced level of growth hormone in nocturnal $\mathrm{GH}$ spontaneous secretion and in the two stimulation tests (with clonidine and insulin); the level of night cortisol was elevated. The test with dexamethasone excluded adrenal failure. The function of thyroid gland and the level of prolactin, $\mathrm{LH}$, and FSH were normal (Table 1). The results of complete blood count, renal and liver function, blood glucose, and routine urinalysis were within normal ranges. However, endocrinology evaluation revealed mildly decreased 25-hydrokxyvitamin D level; no additional disturbances of calcium and phosphate balance were observed.

The bone age, performed according to the Greulich and Pyle method, was significantly delayed (bone age 6 years and 10 months vs. 11 years of chronological age). The radiograph of hands also exposed middle phalange cone-shaped epiphyses, middle phalanges of IV and $V$ fingers, ulnarisation, and shortened metacarpal IV. Chromosomal studies on peripheral lymphocyte culture showed a 46,XX normal female karyotype. $\mathrm{MRI}$ of the brain and hypothalamic-hypophyseal region showed a cyst or microadenoma complicated by haemorrhage. She was qualified to $\mathrm{GH}$ therapy. GH substitution with $0.9 \mathrm{mg} /$ day was started and provided to an increase of height velocity from $4.3 \mathrm{~cm}$ to $8.5 \mathrm{~cm} /$ year during the first year of treatment. No adverse events were observed. The therapy lasted for three years; nevertheless, the patient's final height remained below the $3^{\text {rd }}$ centile $(-3,1 \mathrm{HSDS})$.

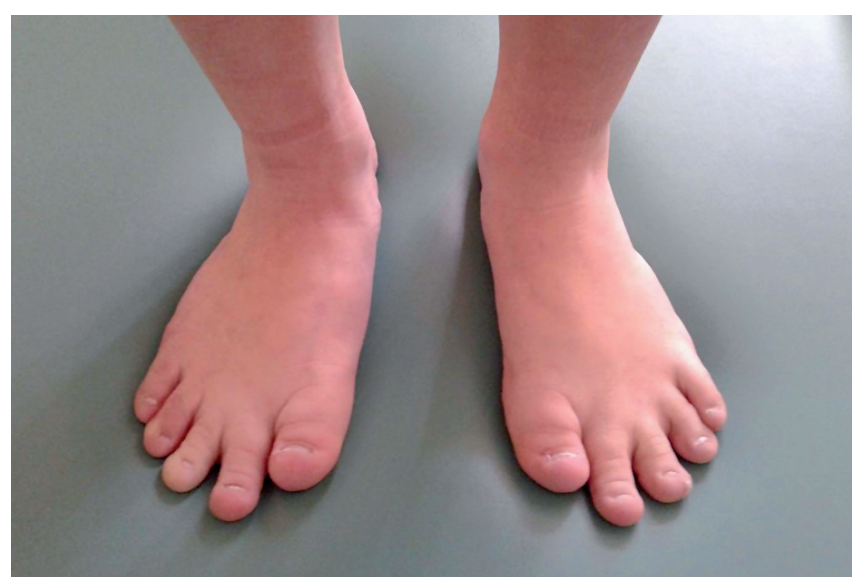

Figure 3. Brachydactyly and clinodactyly of first toes, minor syndactyly of II and III toes, shortening of I, IV, and V metacarpals and hypoplastic nails (Case 3 )

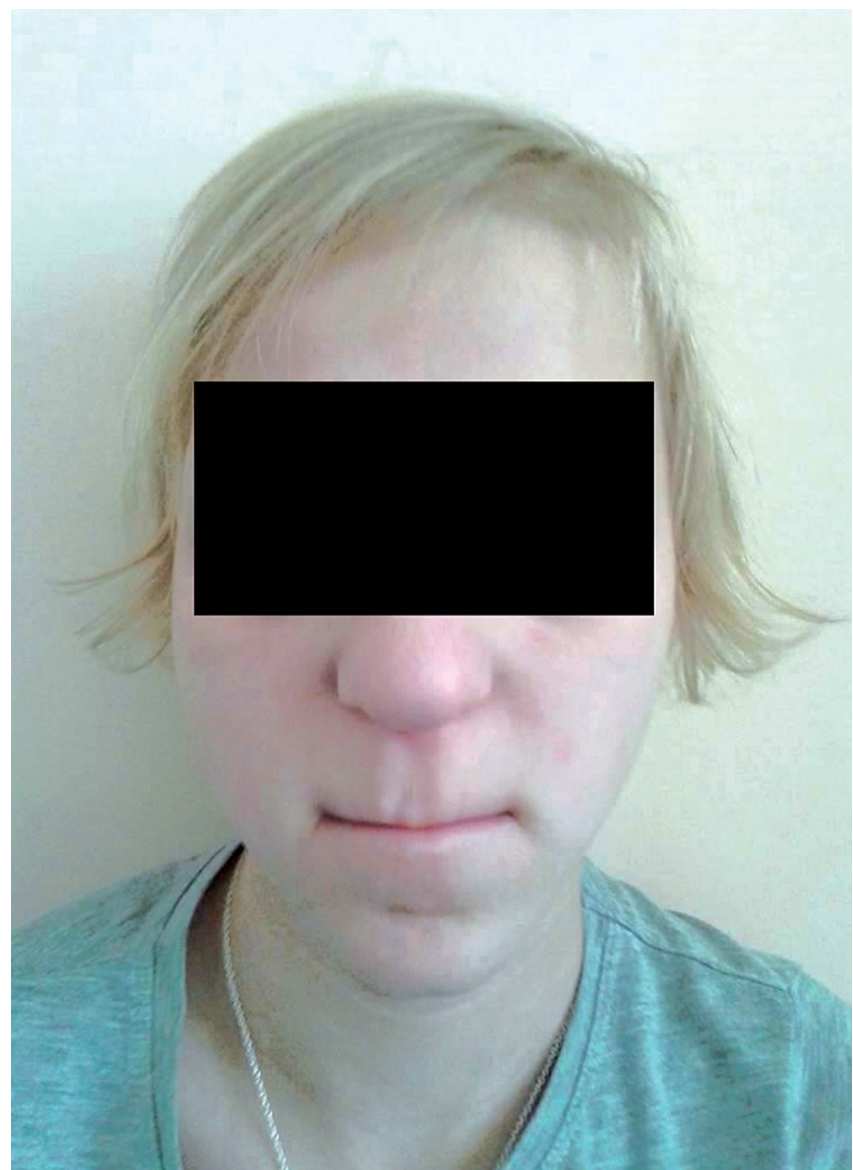

Figure 2. Characteristic facial dysmorphic features, including pear-shaped nose, long flat philtrum, thin upper vermilion border, laterally sparse eyebrows, prognathism, and thin, sparse scalp hair (Case 3)

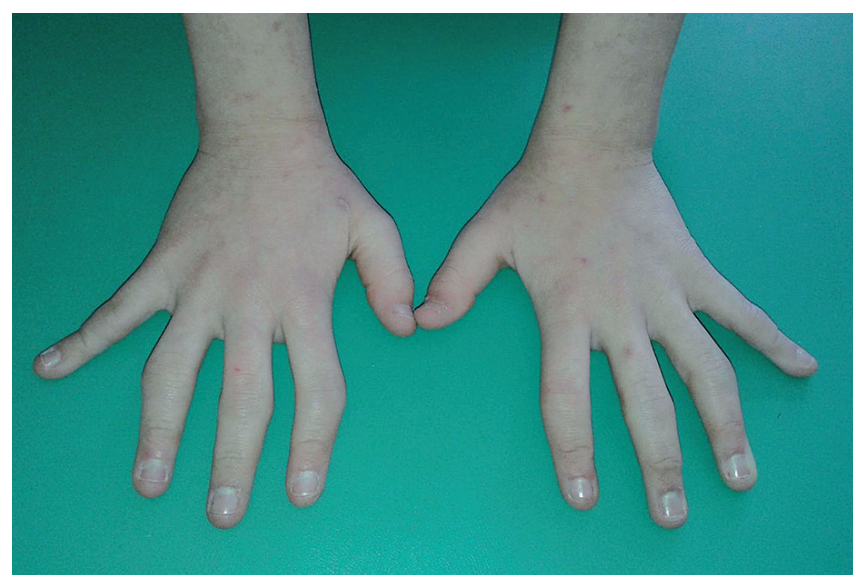

Figure 4. Clinodactyly and ulnar deviation of II digits and radial deviation of IV digits of both hands at the proximal interphalangeal joint (Case 3) 


\section{Discussion}

Trichorhinopharyngeal syndrome is a rare, autosomal dominant skeletal dysplasia caused by a defect involving the TRPS1 gene on chromosome 8 . The syndrome is characterised by the common triad of hair, craniofacial, and skeletal abnormalities $[1,9,11,14]$. Manifestations of the disease present a wide clinical spectrum. The phenotype is variable even in patients with identical mutations or in MZ twins [4, 19, 20]. To date, a few hundred cases of TRPS have been described in the literature, but probably many cases remain undiagnosed or misdiagnosed.

In one of the index patients the disease was probably of autosomal dominant inheritance, because the same disorder was apparent amongst his parents and siblings. The other three individuals were apparently sporadic cases. Three of our patients were female and one was male. All of them presented the typical facial appearance with pear-shaped nose with a bulbous tip, long philtrum, wide mouth, thin upper vermilion border, and fine, sparse hair. It is relevant that the one of the presenting patients had almost complete absence of scalp hair at the age of three years.

Short stature is a common finding in affected individuals [21]. Three of our patients had height below the third centile. The evaluation of growth hormone axis revealed adequate endogenous growth hormone secretion in two of the presented cases. One of the affected children was found to have partial $\mathrm{GH}$ deficiency and was qualified to $\mathrm{GH}$ replacement therapy. A remarkable catch-up growth after the beginning of the treatment was observed.

Recent studies have indicated the possible role of TRPS1 in bone homeostasis, especially in determining bone mineral density. Endocrinology evaluation revealed mildly decreased 25-hydrokxyvitamin D level in three of the index patients. However, no serious additional disturbances of calcium and phosphate balance were observed.

Trichorhinopharyngeal syndrome is also connected with typical skeletal abnormalities [2, 4, 9, 10]. The clinical examination in the majority of presenting patients revealed irregularly short and stubby hands, with clinodactyly of at least one finger. Radiographs, in all of the cases, showed an enlarged, irregular metaphyseal ending, with the shape of a cone or an inverted V. One or more metacarpals were short in two of the index patients. Additionally, in most of the individuals, the skeletal age compared with the chronological age was retarded. However, the coneshaped epiphyses of phalanges are found in many other skeletal dysplasias and also occur in about $5 \%$ of normal children.

Trichorhinopharyngeal syndrome can also mimic juvenile idiopathic arthritis or Perthes disease $[11,22,23]$. One of the in- dex patients presented several atypical rheumatological symptoms, including interphalangeal asymmetric arthritis, and had hypermobility of the joints. She also suffered from chronic hand joint pain and had limitated arm movement.

One of the individuals had Perthes-like left hip deformation, and another had surgical intervention due to bilateral Perthes disease. In cases with bilateral changes affecting the hips, multiple epiphyseal dysplasia must be considered.

The differential diagnosis in patients with alopecia and abnormalities of the nose and hands, also includes the oral-facialdigital syndrome, Larsen's syndrome, alopecia-onychodysplasia, hidrotic ectodermal dysplasia (Cloustron's syndrome), chondroectodermal dysplasia (Ellis-van Creveld syndrome), and Coffin-Siris syndrome [18].

A few studies showed a connection between TRPS and malformation of other organs, including genitourinary tract disorder, mitral valve prolapse, or ventricular septal defect. One of the presented patients had a connate uretero-pelvic junction stricture that required pyeloplasty.

It can be concluded that despite the rarity of the TRPS, primary care physicians, paediatricians, rheumatologists, and endocrinologists should consider this diagnosis when evaluating individuals with characteristic trichological, facial, and skeletal abnormalities. It is noteworthy that clinical features of TRPS may mimic other skeletal dysplasias, Perthes disease or inflammatory arthropathy. The physical examination, radiological findings and genetic analysis are meaningful for diagnosing patients with TRPS. It is postulated that the level of 25-hydroxyvitamin D and DXA scan for affected children and adolescent may be helpful in the detection of early phase osteopaenia and to prevent the development of severe osteoporosis in adulthood. Functional disability or chronic arthralgias may be corrected by orthopaedic procedures.

Several studies showed a possible association between TRPS and growth hormone deficiency and other endocrine disturbances. The affected individuals with short stature need evaluation of the growth hormone axis. It is suggested that $\mathrm{GH}$ therapy could improve growth and bone mineral density in children with growth failure [24, 25].

TRPS may be associated also with renal alteration, genitourinary track malformation, and heart pathology. This fact indicates that TRPS is a multisystemic disorder. At present, specific treatments for TRPS are not available. The cooperation of a multidisciplinary team seems to be essential in the proper management of these patients. Indeed, proper clinical and genetic diagnosis allows adequate and timely therapeutic intervention. 


\section{References}

1. Momeni P, Glöckner G, Schmidt O, et al. Mutations in a new gene, encoding a zinc-finger protein, cause tricho-rhino-phalangeal syndrome type I. Nat Genet 2000; 24: 71-74. doi:10.1038/71717

2. Giedion A. Das trichorhino-phalangeale syndrom. Helv Paediatr Acta 1966; 21: 475-482.

3. Lüdecke HJ, Wagner MJ, Nardmann J, et al. Molecular dissection of a contiguous gene syndrome: localization of the genes involved in the Langer-Giedion syndrome. Hum Mol Genet 1995; 4: 31-36.

4. Lüdecke HJ, Schaper J, Meinecke P, et al. Genotypic and phenotypic spectrum in tricho-rhino-phalangeal syndrome types I and III. Am J Hum Genet 2001; 68: 81-91.

5. Seitz CS, Lüdecke HJ, Wagner N, et al. Trichorhinophalangeal syndrome type I. Clinical and molecular characterization of 3 members of a family and 1 sporadic case. Arch Dermatol 2001; 137: 14371442.

6. Ishimori N, Stylianou IM, Korstanje R, et al. Quantitative trait loci for BMD in an SM/J by NZB/BINJ intercross population and identification of Trps1 as a probable candidate gene. J Bone Miner Res 2008; 23: 1529-1537. doi: 10.1359/jbmr.080414

7. Hecht JT, Hogue D, Wang Y, et al. Hereditary multiple exostoses (EXT); mutational studies of familial EXT1 cases and EXT-associated malignances. Am J Hum Genet 1997; 60: 80-86.

8. Heinritz W, Hüffmeier U, Strenge $S$, et al. New mutations of EXT1 and EXT2 genes in German patients with multiple osteochondromas. Ann Hum Genet 2009; 73: 283-291. doi: 10.1111/j.14691809.2009.00508.x

9. Howell CJ, Wynne-Davies R. The tricho-rhino-phalangeal syndrome. A report of 14 cases in 7 kindreds. J Bone Joint Surg Br 1986; 68: 311-314.

10. Noltorp S, Kristoffersson UL, Mandahl N, et al. Trichorhinophalangeal syndrome type I: symptoms and signs, radiology and genetics. Ann Rheum Dis 1986; 45: 31-36.

11. Dias $C$, Isidoro $L$, Santos $M$, et al. Trichorhinophalangeal Syndrome Type I: A Patient with Two Novel and Different Mutations in the TRPS1 Gene. Case Rep Genet 2013; 2013: 748057. doi: 10.1155/2013/748057.

12. Machuca G, Martinez F, Machuca C, et al. Craniofacial and oral manifestations of trichorhinophalangeal syndrome type I (Giedion's syndrome). Oral Surg Oral Med Oral Pathol Oral Radiol Endod 1997; 84: 35-39.
13. Bauermeister $S$, Letts $M$. The orthopaedic manifestations of the Langer-Giedion syndrome. Ofthop Rev 1992; 21: 31-35.

14. Giedion A. Phalangeal cone-shaped epiphyses of the hand: their natural history, diagnostic sensitivity, and specificity in cartilage hair hypoplasia and the trichorhinophalangeal syndromes I and II. Pediatr Radiol 1998; 28: 751-758. doi: 10.1007/s002470050460

15. Jones KL, Jones MC, del Campo M. Langer-Giedion syndrome Smith's. Recognizable Patterns of Human Malformation. Elsevier Saunders, Philadelphia 2013; 324.

16. Bochkova DN, Kuz'mina NN. Trichorhinophalangeal syndrome in a girl with mitral valve prolapsed. Pediatriia 1979; 8: 65-66.

17. Jungst BK, Spranger J. Ballooning mitral valve in tricho-rhino-phalangeal syndrome. Monatsschr Kinderheilkd 1976; 124: 538-541.

18. Robert SC, Cooper JP. A patient with tricho-rhino-phalangeal syndrome and mitral valve disease. Int J Cardiol 2007; 114: 129-130. doi: 10.1016/j.jijcard.2006.08.011

19. Rossi A, Devirgiliis V, Panasiti V, et al. Missense mutation in exon 7 of TRPS1 gene in an Italian family with a mild form of trichorhinophalangeal syndrome type I. Br J Dermatol 2007; 157: 1021 1024. doi: 10.1111/j.1365-2133.2007.08158.x

20. Vaccaro M, Guarneri F, Barbuzza O, et al. A familial case of trichorhinophalangeal syndrome type I. Pediatr Dermatol 2009; 26: 171 175. doi: 10.1111/j.1525-1470.2009.00905.x

21. Hazan F, Korkmaz HA, Yararbas K, et al. Trichorinophalangeal syndrome type II presenting with short stature in a child. Arch Argent Pediatr 2016; 114: e403-e407. doi: 10.5546/aap.2016.eng.e403

22. McGuire KJ, Westacott S, MacEwen GD. Trichorhinophalangeal syndrome: evolution of Perthes-like changes in the hips. Orthopedics 2000; 23: 855-856.

23. Minguella I, Ubierna M, Escola J, et al. Trichorhinophalangeal syndrome, type I, with avascular necrosis of the femoral head. Acta Paediatr 1993; 82: 329-330.

24. Sarafoglou K, Moassesfar S, Miller BS. Improved growth and bone mineral density in type I trichorhinophalangeal syndrome in response to growth hormone therapy. Clin Genet 2010; 78: 591-593. doi: 10.1111/j.1399-0004.2010.01434.x

25. Stagi S, Bindi G, Galluzzi F, et al. Partial growth hormone deficiency and changed bone quality and mass in type I trichorhinophalangeal syndrome. Am J Med Genet A 2008; 146A: 1598-1604. doi: 10.1002/ajmg.a.32348 